\section{Effects of Water Temperature on the Egg-laying of the Monogenean Neoheterobothrium hirame}

\author{
Nobuyuki Tsutsumi ${ }^{1}$, Keiichi Mushiake ${ }^{2}$, Koh- \\ ichiro Mori², Misao Arimoto ${ }^{2}$, Tomoyoshi \\ Yoshinaga $^{3}$ and Kazuo Ogawa ${ }^{1 *}$ \\ ${ }^{1}$ Laboratory of Fish Diseases, Department of Aquatic \\ Bioscience, Graduate School of Agricultural and Life \\ Sciences, The University of Tokyo, Yayoi, \\ Bunkyo, Tokyo 113-8657, Japan \\ ${ }^{2}$ Kamiura Station of Japan Sea-Farming Association, \\ Kamiura, Minamiamabe, Oita 879-2602, Japan \\ ${ }^{3}$ National Research Institute of Aquaculture, Fisheries \\ Research Agency, Nansei, Mie 519-0193, Japan
}

(Received November 1, 2001)

\begin{abstract}
The egg-laying rates of the monogenean Neoheterobothrium hirame, a parasite of Japanese flounder, were measured at different water temperatures. The daily egg-laying rates per worm were $203,578,781$ and 651 eggs at $10,15,20$ and $25^{\circ} \mathrm{C}$, respectively. Thus the egg-laying rate increases progressively with temperature from 10 to $20^{\circ} \mathrm{C}$, but no significant difference was detected between values at 20 and $25^{\circ} \mathrm{C}$ or between 15 and $25^{\circ} \mathrm{C}$. While all the eggs obtained below $20^{\circ} \mathrm{C}$ appeared normal with straight appendages at both ends, $1.4 \%$ of the eggs obtained at $25^{\circ} \mathrm{C}$ appeared abnormal, suggesting that $25^{\circ} \mathrm{C}$ is at or near the upper limit for the normal egg-laying of this parasite.
\end{abstract}

Key words: Neoheterobothrium hirame, egg-laying, Monogenea, temperature effect, Paralichthys olivaceus

The monogenean parasite Neoheterobothrium hirame Ogawa, 1999 occurs on wild Japanese flounder (Paralichthys olivaceus) in Japanese coastal waters ${ }^{1-4)}$. This parasite infection causes anemia of the host fish ${ }^{5-9}$, which may have a negative impact on wild flounder populations. However, knowledge of the parasite's biology is limited. To understand the ecology of the parasite and to evaluate its impact on wild flounder populations, we examined the egg-laying of $N$. hirame in relation to water temperature to determine its reproductive potential.

\footnotetext{
1 東京大学大学院農学生命科学研究科魚病学研究室

2 日本栽培漁業協会上浦事業場

3 養殖研究所

* Corresponding author

E-mail: aogawak@mail.ecc.u-tokyo.ac.jp
}

\section{Materials and Methods}

Wild Japanese flounder infected with $N$. hirame, were caught in Miyako Bay, Iwate Prefecture, and were used as the parasite egg source. They were transported to Kamiura Station of Japan Sea-Farming Association and maintained in a $500 \mathrm{~L}$ tank with constant water flow at $20^{\circ} \mathrm{C}$. Eggs for the experimental infection of fishes were collected by filtering water draining from the tank containing infected fishes through nylon mesh with a mesh size of $50 \mu \mathrm{m}$. Previous tests had shown that all eggs were retained by mesh of this size.

For the experimental infection, 20 uninfected flounder $(30 \pm 1 \mathrm{~cm}$ in total length) were placed together with about 1200 parasite eggs in a recirculating tank $(500 \mathrm{~L})$ equipped with a biological filter system. The fish were maintained in the tank at $20^{\circ} \mathrm{C}$ and fed dry pellets once a day for longer than 2 months. Some of the experimentally infected fish that were seemingly not anemic with normal gill color were used for measurement of the egglaying rates of the parasite. Each fish was placed in a recirculating tank $(25 \mathrm{~L})$ at a different time post-infection and gradually acclimated over a 3 day period to the fixed experimental temperature $\left(10,15,20\right.$ or $\left.25^{\circ} \mathrm{C}\right)$. Subsequently, each acclimated fish was transferred to another $20 \mathrm{~L}$ tank, the water temperature of which was controlled in a water bath, and the water in the tank was changed every day for 3 days. From 1 week after the transfer, the water was filtered through $50 \mu \mathrm{m}$ mesh every day for 3 days to measure the egg-laying rate; eggs trapped by the filter were collected and counted under a stereomicroscope. After the measurement, the fish was sacrificed to count infecting parasites and the daily egg-laying rate per worm was calculated. During the whole period after the transfer to the acclimation tank, the fish were kept without feeding. Two separate trials were conducted at each temperature.

\section{Results}

The mean daily egg-laying rates at different water temperatures are shown in Table 1. As no significant difference was detected between the two trials at any temperature, the data were combined for statistical analysis. As shown in the table, the egg-laying rates increased with increasing temperature from 10 to $20^{\circ} \mathrm{C}$, whilst no significant difference was detected between egg-laying rates at 15 and $25^{\circ} \mathrm{C}$ or at 20 and $25^{\circ} \mathrm{C}$. All the eggs obtained at or below $20^{\circ} \mathrm{C}$ appeared normal, with spindle-shaped capsules and straight appendages at both ends. Their dimensions, including the appendages, were 493-750 $\mu \mathrm{m}$ (mean $602 \mu \mathrm{m}$ ) in length and 50-70 $\mu \mathrm{m}$ (mean $60 \mu \mathrm{m})$ in width $(\mathrm{n}=50)$. However, $1.4 \%$ of the parasite eggs obtained at $25^{\circ} \mathrm{C}$ appeared abnormal, with deformed shells and appendages deformed, short or absent (Fig. 1). 
Table 1. Effect of water temperature on the egg-laying rate of Neoheterobothrium hirame

\begin{tabular}{|c|c|c|c|c|c|c|c|c|c|c|}
\hline \multirow{3}{*}{$\begin{array}{c}\text { Water } \\
\text { temperature } \\
\left({ }^{\circ} \mathrm{C}\right)\end{array}$} & \multicolumn{4}{|c|}{ 1st trial } & \multicolumn{4}{|c|}{ 2nd trial } & \multirow{2}{*}{\multicolumn{2}{|c|}{$\begin{array}{c}\text { Total } \\
\text { Egg-laying rate } \\
\text { (eggs/worm/day }\end{array}$}} \\
\hline & \multirow{2}{*}{$\begin{array}{r}\text { Days post } \\
\text { infection }\end{array}$} & \multirow{2}{*}{$\begin{array}{l}\text { No. of } \\
\text { worms }\end{array}$} & \multicolumn{2}{|c|}{$\begin{array}{l}\text { Egg-laying rate } \\
\text { (eggs/worm/day) }\end{array}$} & \multirow{2}{*}{$\begin{array}{c}\text { Days post } \\
\text { infection }\end{array}$} & \multirow{2}{*}{$\begin{array}{l}\text { No. of } \\
\text { worms }\end{array}$} & \multicolumn{2}{|c|}{$\begin{array}{l}\text { Egg-laying rate } \\
\text { (eggs/worm/day) }\end{array}$} & & \\
\hline & & & Mean* & SD & & & Mean* & SD & Mean** & SD \\
\hline 10 & $78-80$ & 1 & 185 & 40 & $108-110$ & 3 & 221 & 83 & $203^{a}$ & 52 \\
\hline 15 & $88-90$ & 1 & 561 & 99 & $118-120$ & 3 & 593 & 71 & $577^{\mathrm{bc}}$ & 58 \\
\hline 20 & $68-70$ & 2 & 785 & 51 & $128-130$ & 3 & 776 & 202 & $781^{d}$ & 96 \\
\hline 25 & $98-100$ & 1 & 643 & 117 & $138-140$ & 8 & 658 & 174 & $651^{c d}$ & 109 \\
\hline
\end{tabular}

* No significant difference was detected in the mean values between the 1st and 2nd trials at any temperature (Student's t-test, P>0.05).

** Values in the 1st and 2nd trials were combined for stastical analysis, because no difference was detected between the trials.

Values with the same superscript were not significantly different (Scheffe's multiple comparison, $P>0.05$ ).

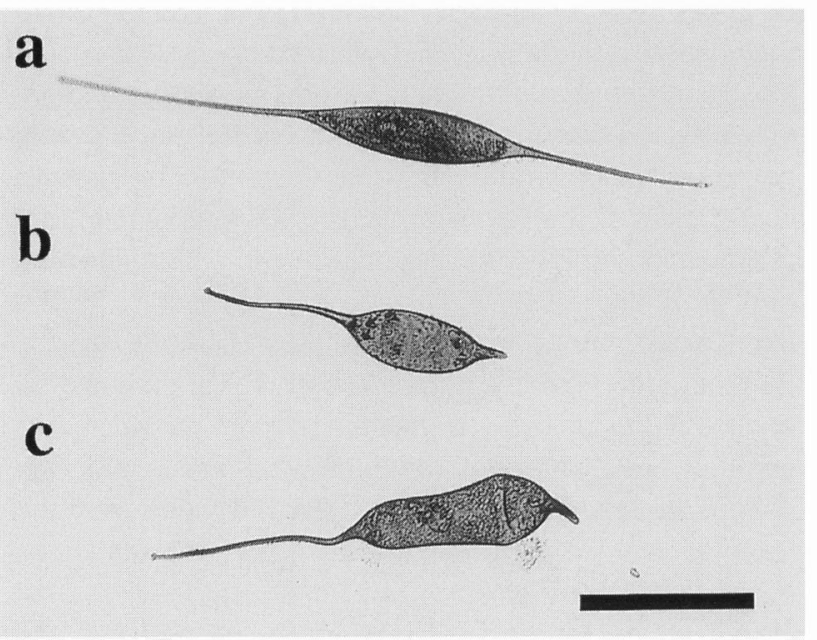

Fig. 1. The eggs of Neoheterobothrium hirame obtained at $25^{\circ} \mathrm{C}$. A normal egg (a) and abnormally shaped eggs (b and c). Bar $=200 \mu \mathrm{m}$.

\section{Discussion}

The egg-laying rate of $N$. hirame is likely to be affected by the age of the parasite and the hematological condition of the host as well as by water temperature. Although the corresponding egg-laying rates at each temperature were measured at different times post-infection in the two trials, no significant difference was detected in the rates between the 1st and 2 nd trials at any temperature, suggesting that the obtained values were for fully mature worms. Moreover, the measurements were carried out using non-anemic flounder i.e. with normal gill color, suggesting that all the worms had an adequate food supply. Therefore, the values obtained in this study probably represent natural egg-laying rates for the parasite.

Egg-laying rates increased with temperature between 10 and $20^{\circ} \mathrm{C}$ and all of those eggs appeared normal, with dimensions consistent with those previously reported by Yoshinaga et al. ${ }^{5)}$ However, there was no significant difference between egg output at 20 and $25^{\circ} \mathrm{C}$ or between values at 15 and $25^{\circ} \mathrm{C}$, and $1.4 \%$ of eggs produced at $25^{\circ} \mathrm{C}$ were abnormal. This indicates that $25^{\circ} \mathrm{C}$ is at or near the upper limit for normal egg-laying in this parasite.

There have been a few reports concerning egg-laying rates of monogenean. The rates of Entobdella solea, Benedenia seriolae, Neobenedenia girellae, $N$. melleni, all of which are capsalid monogeneans infecting the skin and fins of marine fishes, were 30-60, 648 (at $20^{\circ} \mathrm{C}$ ), 293-850 (at $27-30^{\circ} \mathrm{C}$ ) and $144-720$ eggs per worm a day $(e / w / d)$, respectively ${ }^{10-13)}$. The rate of Discocotyle sagittata, which is a discocotylid monogenean infecting the gill of rainbow trout (Oncorhynchus mykiss) was $12.2 \mathrm{e} / \mathrm{w} / \mathrm{d}$ at $18^{\circ} \mathrm{C}^{14)}$. The rate of Polystoma integrrimum, which is a polystomatid monogenean infecting the urinary bladder of the African clawed toad (Xenopus laevis) was $2500 \mathrm{e} / \mathrm{w} / \mathrm{d}^{15)}$. The maximum egg-laying rate of $N$. hirame, which infects the buccal cavity wall of Japanese flounder, demonstrated in the present study was $780 \mathrm{e} / \mathrm{w} / \mathrm{d}$ at $20^{\circ} \mathrm{C}$. Generally, the egg-laying rates of monogeneans are expected to be related to the biology or the survival strategy of each species. However, the rates greatly varied among species, and any relation was not found between the egglaying rates and either of the habitats or classification. More data should be compiled to clarify the relation between egg-laying rates and the survival strategies of monogeneans.

\section{References}

1) Michine, A. (1999): Res. Shimane Pref. Center Cult. Fish., 2, 15-23. 2) Miwa, S. and K. Inouye (1999): Fish Pathol., 34, 113-119. 3) Ogawa, K. (1999): Fish Pathol., 34, 195-201. 4) Anshary, H., K. Ogawa, M. Higuchi and T. Fujii (2001): Fish Pathol., 36, 27-32. 5) Yoshinaga, T., I. Segawa, T. Kamaishi and M. Sorimachi (2000): Fish Pathol., 35, 85-88. 6) Yoshinaga, T., T. Kamaishi, I. Segawa, A. Kumagai, C. Nakayasu, K. Yamano, T. Takeuchi and M. Sorimachi (2000): Fish Pathol., 35: 131-136. 7) Yoshinaga, T., T. Kamaishi, I. Segawa, K. Yamano, H. Ikeda and M. Sorimachi (2001): Fish Pathol., 36, 13-20. 8) Mushiake, M., K. Mori and M. Arimoto (2001): Fish Pathol., 36, 125-132. 9) Yoshinaga, T., T. 
Kamaishi, H. Ikeda and M. Sorimachi (2001): Fish Pathol., 36, 179-182. 10) Kearn, G. C. (1985): Int. J. Parasitol., 15, 187194. 11) Kearn, G. C., K. Ogawa and Y. Maeno (1992): Publ. Seto Mar. Biol. Lab., 35, 351-362. 12) Bondad-Reantaso, M. G., K. Ogawa, M. Fukudome and H. Wakabayashi (1995): Fish
Pathol., 30, 227-231. 13) Jahn, T. L. and L. R. Kuhn (1932): Biol. Bull., 62, 89-111. 14) Gannicott, A. M. and R. C. Tinsley (1998): Parasitol., 117, 499-504. 15) Combes, C. (1972): Int. J. Parasitol., 2, 233-238. 